\title{
PICTORICAL WARNING PADA KEMASAN ROKOK: KOMUNIKASI PERSUASIF DALAM KAMPANYE KESEHATAN
}

\author{
Sherly Hindra Negoro \\ Prodi Ilmu Komunikasi Universitas Atma Jaya Yogyakarta \\ sherlyhindranegoro@yahoo.co.id
}

\begin{abstract}
Smoking has became the serious problem which always to be the classical dynamic of health communication's field. Through health campaign by using pictorical warning in cigarette packs, Indonesian Government has priority to reduce the number of smokers in Indonesia. Pictorical warning in cigarette packs was regard as one of communication strategic for implementing. Health campaign has outcome that could change the health behavior for the persuadee. Visualization by using image becomes persuasive communication tools cigarette packs as the communication media. EPPM model was used to analysis this case. This paper was using literature study to understand this problem.
\end{abstract}

Keywords: Persuasive Communication, Health Campaign, Pictorical Warning

\begin{abstract}
Abstrak
Aktivitas merokok menjadi permasalahan yang menjadi dinamika klasik pada ranah kesehatan. Melalui kampanye kesehatan yang berupa pencantuman "gambar seram" pada kemasan rokok, pemerintah Indonesia berupaya menekan jumlah perokok yang ada di Indonesia. Gambar seram pada kemasan tersebut dianggap sebagai salah satu strategi komunikasi yang dapat diimplementasikan. Dengan adanya kampanye kesehatan ini diharapkan adanya perubahan perilaku hidup sehat yang lebih baik. Visualisasi dengan menggunakan gambar menjadi alat komunikasi persuasif dengan kemasan rokok sebagai media perantaranya. Model EPPM (Extended Parallel Process Model) digunakan untuk menganalisis kasus ini. Tulisan ini menggunakan studi literatur untuk lebih menggali secara komprehensif mengenai kasus ini.
\end{abstract}

Kata Kunci: Komunikasi Persuasif, Kampanye Kesehatan, Peringatan Bahaya Bentuk Gambar

\section{PENDAHULUAN}

Permasalahan mengenai aktivitas merokok sudah menjadi permasalahan yang global dan terus menimbulkan polemik. Kebijakan pemerintah pada setiap negara berbedabeda. Australia misalnya, pada 1 Desember 2012 pemerintah menetapkan aturan bahwa kemasan rokok tidak boleh mencantumkan merek rokok. Di tahun 2015, Pemerintah
Inggris dan Skotlandia mengadopsi aturan dari Australia (Ardiansyah, 2014). Berbagai aturan ini pada akhirnya dibuat dengan tujuan menurunkan jumlah perokok di seluruh dinia.

Sebagai bentuk dari keprihatinan dari aktivitas merokok, muncullah gagasan mengenai hari tembakau sedunia atau dikenal dengan HTTS. Berdasarkan data 
yang diperoleh dari The Tobacco Atlas 3rd edition (2009) dikemukakan bahwa 10 persen dari perokok di seluruh dunia berasal dari ASEAN. Selain itu, dikemukakan juga bahwa Indonesia merupakan negara di ASEAN yang 46,6\% adalah perokok (Infodatin, n.d). Dari catatan WHO disebutkan bahwa rokok merupakan pembunuh utama. 8,2 juta orang meninggal karena karena kanker, 20 persen diantaranya meninggal karena perilaku merokok (Ilham, 2015). WHO (dalam pedoman KTR, 2011) juga mencatat bahwa Indonesia merupakan negara dengan jumlah perokok terbesar ketiga setelah China dan India.

Negara-negara di dunia memiliki kepedulian mengenaiaktivitas merokokyang terus meningkat. Oleh sebab itu, beberapa negara di dunia menerapkan aturan gambar seram pada kemasan rokok di negaranya. Penggunaan gambar seram pada kemasan rokok sudah diikuti 80 negara di dunia. Akan tetapi, belum ada data yang pasti apakah ada hasil penurunan jumlah perokok (Ardiansyah, 2014). Pada24Juni 2014, pemerintah Indonesia menetapkan kebijakan baru mengenai pesan bahaya merokok yang harus tercantum pada kemasan rokok. Hal tersebut tertuang pada Peraturan Pemerintah Nomor 109 Tahun 2012 yang menyatakan bahwa 40 persen kemasan rokok mencantumkan gambar "seram" dan harus berwarna (Sipuu,n.d). Seperti yang diketahui bahwa sebelumnya peringatan bahaya merokok di Indonesia berupa tulisan yang bunyinya "merokokdapat menyebabkan kanker, serangan jantung, impotensi, dan gangguan kehamilan dan janin.

Penerapan visualisasi peringatan bahaya merokok pada kemasan rokok menimbulkan pro dan kontra bagi konsumen maupun industri rokok. Bagi pengusaha rokok, adanya gambar seram dapat memengaruhi penurunan omset penjualan. Akan tetapi, dengan adanya gambar seram pada kemasan rokok dinilai tidak akan membuat konsumen beralih pada merek rokok lainnya (Utama, 2014). Di sisi lain, menurut YLKI aturan tersebut melindungi konsumen dan menegaskan bahwa gambar seram hanya sebagai peringatan bukan melarang konsumen untuk merokok (Deny, 2014).

Pemerintah Indonesia sendiri memiliki tujuan yang baik pada penerapan aturan tersebut. Melihat keprihatinan jumlah perokok yang terus meningkat, menjadikan peraturan ini sebagai salah satu alat untuk mengendalikan jumlah perokok. Data yang diperoleh menyatakan bahwa jumlahperokok di Indonesia meningkat dari tahun ke tahun. Berdasarkan Riset Kesehatan Dasar 2013 yang dilakukan oleh Kementerian Kesehatan RI, menunjukkan bahwa jumlah perokok terutama yang berusia diatas 15 tahun mengalami peningkatan dari 34,2\% pada 2007 menjadi 36,2\% pada 2013 (Puput, 2014).

Penggunaan visualisasi dalam bentuk gambar yang 'menyeramkan' menjadi kajian dalam ranah komunikasi. Komunikasi menurut pandangan dari Engel (Blythe, 2001: 2) merupakan bentuk proses transaksional diantara dua atau lebih partisipan dengan makna yang dipertukarkan menggunakan simbol. Komponen yang ada di dalamnya meliputi, tulisan, gambar, musik, atau aspek lainnya. Merujuk dari pandangan tersebut, dapat disimpulkan bahwa dengan adanya penggunaan simbol tertentu maka suatu komunikasi yang diharapkan akan tercapai. Konteks persuasif pada pictorical warning ini melihat gambar sebagai bagian dari komponen komunikasi persuasif yang tujuannya dapat memengaruhi persuadeenya (dalam hal ini adalah perokok). Sementara itu, media kemasan rokok dijadikan sebagai alat untuk mengkomunikasikan maksud dari pemerintah di dalam mengurangi jumlah perokok di Indonesia.

Kemasan rokok dijadikan sebagai media dalam mengomunikasikan bahaya dari merokok. Schneider et al (Ferguson, 2013) mengemukakan bahwa dengan adanya penggunaan penampilan yang menyeramkan yang didasarkan pad suatu ide tertentu memungkinkan seseorang akan lebih memperhatikan pesan dan selanjutnya akan bertindak di dalam merubah perilaku kesehatannya sesuai dengan ketakutan atau kekhawatiran yang terbentuk. Di sisi yang lain, penggunaan kemasan rokok ini 
justru dipandang sebagai salah satu cara mengomunikasikan konsumen pada suatu brand rokok (Wakefield dalam McCool, 2012). Dapat disimpulkan bahwa kebijakan mengenai penggunaan gambar seram pada kemasan rokok menjadi kontradiksi dari sisi pemasaran terutama brand yang masih ada pada kemasan rokok. Hammond (dalam McCool, 2012) menuturkan bahwa kemasan rokok yang justru dibuat polos tanpa menampilkan merek menjadi pilihan. Dengan membuat kemasan rokok menjadi polos, akan meningkatkan efektivitas peringatan kesehatan, mengurangi kepercayaan yang salah tentang rokok, dan mengurangi ketertarikan konsumen pada merek rokok.

Kebijakan pemerintah terkait penggunaangambarseraminiterkaitdenganaspek kampanye kesehatan. Hal yang ditekankan adalah perubahan perilaku perokok untuk mengurangi jumlah perokok yang ada di Indonesia pada khususnya, dalam aspek akademis, penelitian yang terkait dengan kampanye kesehatan berfokus pada aspek demografis dan psikografis, yang meliputi usia, jenis kelamin, status minoritas, dan kepercayaan tentang kesehatan (Moorman dan Matulich dalam Kim, 2003). Kampanye kesehatan merupakan bentuk potret dari strategi di dalam mempersuasi orang lain guna merubah perilaku sesuai yang diharapkan sebagai tujuan akhir dari kampanye tersebut.

Bentuk lain sebagai upaya pemerintah di dalam menekan perokok adalah dengan cara membatasi ruang gerak para perokok dengan menetapkan kawasan bebas asap rokok. Akan tetapi, nampaknya sulit merealisasikan hal tersebut untuk menekan jumlah perokok dikarenakan iklan rokok dan konsumsi rokok (Pedoman KTR, 2011). Lebih dari itu, penetapan kawasan tanpa rokok merupakan bagian dari upaya untuk memberikan hak kepada masyarakat untuk menghirup udara segar.

Tulisan ini mengkaji terkait permasalahan yang didasarkan pada data-data dan juga mengaitkan dengan konteks komunikasi. Konteks komunikasi yang dimaksud adalah dengan melihat pesan bahaya rokok yang disampaikan melalui pictorical warning pada kemasan rokok sebagai alat komunikasi persuasif. Selain itu, tulisan ini akan menggunakan model EPPM (Extended Parallel Process Model) sebagai landasan berpikir dengan menguraikan permasalahan yang terjadi dan teorisasinya.

\section{LANDASAN TEORI}

\section{Komunikasi Persuasif dalam Aktivitas Kampanye}

Tidak bisa dipungkiri bahwa aspek komunikasi menjadi kebutuhan dasar yang sehari-hari dilakukan oleh manusia. Jika merujuk pada model komunikasi sebagai konstruksi dasar berpikir, Berlo (dalam Mulyana, 2007) menyebutkan bahwa model komunikasi yang dilakukan manusia berpola pada SMCR. Kemudian, model ini dapat dimaknai sebagai Source (S), Message (M), Channel (C), dan Receiver (R). Sumber mengacu pada pihak yang menciptakan pesan baik personal maupun kelompok. Pesan mengacu pada terjemahan gagasan ke dalam kode-kode simbolik. Saluran adalah medium untuk membawa pesan tersebut. Penerima pesan dimaknai sebagai orang yang menjadi sasaran komunikasi.

Konteks komunikasi pada komunikasi persuasif juga berpijak pada model tersebut, sehingga, model ini juga dapat diaplikasikan. Apabila dikaitkan dengan konteks persuasi, sumber atau source dimaknai sebagai persuader. Kemudian, penerima pesan atau receiver dimaknai sebagai persuade atau orang yang diterpa pesan persuasi.

Terkait dengan esensi sebuah pesan, pesan yang ingin disampaikan dapat dilakukan secara beragam dan berbagai cara dan disesuaikan dengan komunikator. Griffin (2003: 7) mengemukakan bahwa frasa pada suatu pesan mengindikasikan isi dan bentuknya yang selalu dikonstruksikan, diciptakan, direncanakan, dikarang, didapatkan, dipilih, dan diadopsi oleh komunikator.

Komunikasi persuasif memiliki peranan yang cukup penting di dalam sebuah aktivitas kampanye. De Vito (2011) 
mengemukakan bahwa usaha yang dilakukan dalam persuasi adalah dengan memusatkan perhatian pada usaha dan upaya mengubah dan memperkuat sikap atau kepercayaan khalayak atau mengajak mereka untuk bertindak sesuai dengan cara tertentu. Sementara itu Bettinghaus (Perloff, 2003: 8) dalam bukunya mengemukakan bahwa persuasif merupakan "Upaya sadar oleh satu individu untuk mengubah sikap, keyakinan, atau perilaku individu lain atau kelompok individu melalui transmisi atau pesan”. Dari berbagai pengertian persuasif, Perloff (2003) menyimpulkan bahwa ada lima komponen penting, yang meliputi:

1. Persuasi berkaitan dengan proses simbolik

Konteks ini lebih menekankan pada penggunaan simbol-simbol dengan pesan tertentu yang kemudian disampaikan. Makna yang terkandung dalam simbol tersebut dikaitkan dalam konteks kebudayaan tertentu.

2. Persuasi melibatkan bujukan untuk memengaruhi

Dalam konteks ini, persuasi tidak selalu sukses untuk dilakukan atau terkadang gagal untuk menjangkau target sasaran. Akan tetapi, persuader harus memiliki maksud untuk merubah sikap atau perilaku persuade dan dilakukan dengan kesadaran untuk mencapai maksud tersebut.

3. Seseorang mempersuasi dirinya sendiri Dalam konteks ini, persuader seharusnya mampu mempersuasi dirinya terlebih dahulu untuk berubah baru melakukan persuasi untuk persuade. Selain itu, persuader tidak boleh memaksa orang lain untuk berubah tetapi melakukan komitmen bahwa perubahan datangnya dari diri sendiri.

4. Persuasi melibatkan transmisi pesan

Dalam konteks ini, pesan dapat dikomunikasikandalambentukverbaldan nonverbal. Pesan yang dibuat disesuaikan dengan persuade yang bertujuan untuk merubah sikap atau perilaku seseorang.
5. Persuasi membutuhkan pilihan yang bebas

Persuasi diri adalah kunci keberhasilan persuasi. Kemudian individu akan menentukan perilakunya sendiri.

Dalam konteks persuasif, terdapat aspek psikologis yang dilibatkan misalnya dengan menggunakan fear appeal. Fear appeal dimaknai sebagai "Komunikasi persuasif yang mencoba untuk menakuti seseorang untuk merubah sikapnya dengan meningkatkan konsekuensi atau dampak negatif yang akan terjadi jika mereka memenuhi rekomendasi suatu pesan.” (Perloff, 2003: 187). Berkaitan dengan pendapat tersebut, dapat dilihat bahwa strategi komunikasi persuasif dapat dilakukan dengan menggunakan pesan yang dianggap "menyeramkan" yang kemudian dapat mengganggu psikologis seseorang. Output yang ingin didapatkan adalah seseorang mampuuntukmelakukantindakan sesuai dengan isi pesan yang disampaikan.

\section{Kampanye Kesehatan}

Kampanye kesehatan memiliki kaitan komunikasi dalam ranah kesehatan. Komunikasi kesehatan menurut Schiavo (dalam Harrington, 2015, h.8) didefinisikan sebagai "pendekatan multidispliner untuk menjangkau target audiens dan membagikan informasi tentang kesehatan dengan tujuan memengaruhi, mendekatkan, membantu individu, komunitas, profesional kesehatan, kelompok tertentu, pembuat kebijakan dan publik untuk mengenalkan, mengadopsi, atau mengembangkan perilaku, praktek, atau kebijakan yang dapat meningkatkan hasil yang baik untuk kesehatan".

Proses di dalam melakukan kampanye kesehatan upaya untuk meningkatkan kesadaran masyarakat akan hidup sehat bukan menjadi perkara yang mudah. Hal tersebut terkait dengan cara mengedukasi masyarakat dengan berbagai karakter serta latar belakang. Sebagai upaya dari penyadaran akan pentingnya kesehatan dan upaya perubahan perilaku hidup sehat, kampanye kesehatan publik atau masyarakat dimaknai 
sebagai "upaya untuk mempersuasi publik tertentu untuk melibatkan masyarakat dalam perilaku tertentu sebagai upaya meningkatkan kesehatan masyarakat atau mencegah dari perilaku yang tidak sehat." (Heath, 2005: 669). Merujuk pada pengertian tersebut bahwa dapat dilihat bahwa adanya kampanye kesehatan yang dilakukan oleh pihak tertentu memiliki tujuan di dalam mencapai pola kesehatan publik yang lebih baik.

Konteks persuasi mengharapkan adanya perubahan perilaku sesuai dengan yang diharapkan. Perubahan perilaku tersebut, dapat dilakukan secara bertahap. Fishbein (Gelders, 2009: 352) menyatakan bahwa terdapat tiga aspek yang melandasi atau menentukan perilaku seseorang, yaitu keyakinan, norma subjektif, dan keampuhan persepsi. Thomas (2006: 66) menyebutkan bahwa terdapat lima tahapan yang melandasi seseorang melakukan suatu perubahan. Tahapan tersebut meliputi, precontemplation, contemplation, decision/ determination, Action, Maintenance.

Dalam pendekatan public relations saat melakukan kampanye, aspek yang menjadi sangat penting adalah perencanaan. Gregory (2010) memaparkan tujuh alasan dalam suatu perencanaan. Pertama, perencanaan memiliki fokus pada suatu usaha yang dilakukan. Usaha yang dilakukan adalah hal yang benar secara efektif dan efisien karena dua aspek ini penting yang disesuaikan dengan sumber daya. Kedua, perencanaan dapat meningkatkan efektivitas. Maksudnya adalah dengan melakukan hal yang baik maka tujuan yang diharapkan akan dapat dicapai. Apabila suatu tujuantelahditetapkan akan tetapi belum tercapai, maka, perlu dilakukan tinjauan kembali hal-hal yang menjadi penghambat atau kegagalan. Ketiga, perencanaan mendorong pada tinjauan jangka panjang. Kajian terkait dengan sejarah atau evaluasi dari yang pernah dilakukan harus dilakukan. Mengingat hal yang direncanakan melihat tren yang sedang terjadi.

Keempat, membantu di dalam mendemonstrasikan nilai dari uang. Hal yang dimaksud adalah "apa yang didapatkan dengan sejumlah uang yang telah dikeluarkan atau diinvestasikan". Kelima, meminimalisir terjadinya hal yang tidak diinginkan. Perencanaan yang baik adalah merencanakan ketika hal buruk terjadi dan kemudian mampu melakukan identifikasi permasalahan dengan berbagai scenario yang telah disiapkan. Keenam, mendamaikan atau meredam konflik. Kampanye merupakan aktivitas yang dapat menimbulkan konflik kepentingan maupun prioritas. Oleh sebab itu, perlu dilakukan pelibatan stakeholder terkait supaya usaha di dalam menyampaikan pesan persuasif dapat dilakukan. Ketujuh, memfasilitasi pihak yang proaktif. Dalam hal ini, praktisi perlu mempertimbangkan reaksi dari media menjadikan sebuah isu penting untuk dibahas.

\section{Model EPPM (Extended Parallel Process Model)}

Model EPPM yang dikemukakan oleh Kim Witte seringkali digunakan pada kampanye komunikasi, baik dalam ranah kesehatan maupun ranah politik. Teori ini lebih berfokus pada penggunaan gambar seram akan memiliki dampak yang efektif maupun tidak efektif dalam hal penyampaian suatu pesan persuasif (Littlejohn, 2009: 9o). Penggunaan pesan yang menyeramkan sebagai pesan persuasif dibuat dengan tujuan membuat ketakutan pada persuadee. Pesan yang menyeramkan mendeskripsikan gambaran pada saat persuadee tidak menjalankan sesuai dengan pesan yang disampaikan.

Model EPPM (dalam Perloff, 2003: 191) juga menjelaskan bahwa ada empat elemen di dalam sebuah pesan persuasif, yang meliputi:

1. Severity information

Informasi tentang keseriusan atau besarnya suatu ancaman. Misalnya penggunaan pesan "Mengonsumsi makanan yang berlemak akan meningkatkan resiko terkena serangan jantung."

2. Susceptibility information

Informasi mengenai kemungkinan ancaman muncul. Misalnya "Orang 
yang suka mengonsumsi junk food, akan berrsiko terkena serangan jantung sebelum usia 40 tahun."

3. Response efficacy

Informasi mengenai efektivitas dari tindakan yang dianjurkan. Misalnya “ Menjaga pola makan dengan diet buah dan sayur, akan mengurangi resiko serangan jantung."

4. Self-efficacy information

Argumentasi dari individu yang mampu membentuk hal-hal yang dianjurkan. Misalnya "Anda dapat mengganti diet anda, semua orang sudah mencoba."

Asumsi yang diungkapkan dalam teori ini adalah apabila ancaman tinggi dan respon yang positif juga tinggi, maka penerima pesan akan melakukan sesuatu yang berkaitan dengan perubahan. Hal ini dikarenakan adanya pesan tersebut dirancang untuk suatu tujuan atau ada suatu masalah sehingga ada perasaan untuk melakukan sesuatu. Asumsi yang lain menyebutkan bahwa jika ancaman tinggi tetapi respon yang positif rendah, maka penerima pesan tidak akan menerima pesan dan lebih baik untuk menghindar atau melakukan hal-halyang bertentangandengan isi pesan yang disampaikan (Littlejohn, 2009, h.90).

Model dari teori ini dapat digambarkan sebagai berikut:

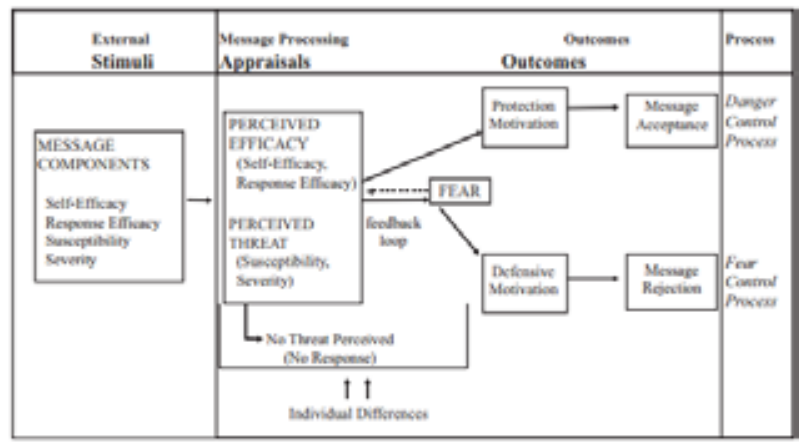

Gambar 1 Model EPPM (Witte dalam Popova, 2012: 456)

Berdasarkan model tersebut, penjelasan konseptual (Witte dalam Popova, 2012: 458) dapat dijelaskan sebagai berikut:
1. Fear

Reaksi emosional yang negatif yang berkaitan dengan dimensi psikologis dan fisiologis oleh ancaman yang serius atau ancaman yang terkait dengan dirinya.

2. Perceived Threat

Pengetahuan tentang bahaya yang ada di lingkungan sekitarnya. Ancaman berkaitan dengan dimensi kerumitan dan kerentanan.

3. Perceived Severity

Keyakinan mengenai pentingnya dan besarnya ancaman. Keyakinan ini didasarkan pada beban yang harus didapatkan ketika kejadian terjadi.

4. Perceived Susceptibility

Keyakinan mengenai resiko yang dialami seseorang.

5. Efficacy

Pengetahuan tentang efektivitas, kelayakan, dan kemudahan dengan rekomendasi untuk menghindari sebuah ancaman.

6. Self-efficacy

Keyakinan seseorang di dalam memberikan tanggapan yang direkomendasikan untuk menghindari ancaman tersebut.

7. Response efficacy

Keyakinan seseorang mengenai efektivitas yang direkomendasikan dalam menghindari suatu ancaman.

\section{Danger Control}

Proses kognisi yang memunculkan motivasi yang muncul ketika suatu keyakinan yang lebih efektif di dalam mencegah secara signifikan dan ancaman tersebut revelan di dalam mengubah perlindungan diri. Pada saat dalam kontrol bahaya, seseorang akan lebih memikirkan strategi mencegah terjadinya suatu ancaman.

\section{Danger Control Responses}

Kepercayaan, sikap, niat, dan perubahan perilaku pada kesesuaian dengan pesan yang dianjurkan. 


\section{Fear Control}

Proses emosional menimbulkan pembelaan motivasi yang terjadi ketika seseorang dihadapkan pada ancaman yang berkaitan, akan tetapi, kepercayaan mereka sendiri tidak menunjukkan anjuran di dalam merespon atau menjadi tidak efektif.

\section{Fear Control Responses}

Respon yang dapat mengatasi ketakutan misalnya dengan menghindari dan menolak.

Terkait dengan isi pesan yang emosional yang digunakan sebagai strategi persuasif, Smith (Gregory, 2010) menyebutkan bahwa ada dua hal strategiyang dapat memunculkan emosi negatif dari penerima pesan, yaitu fear appeals dan guilt appeals.

\section{HASIL DAN PEMBAHASAN}

Berpijak pada telaah teori diatas, ranah kampanye kesehatan menjadi salah satu alat di dalam melakukan persuasi. Konteks persuasi nampak pada visualisasi pada kemasan rokok yang menjadi kebijakan pemerintah Indonesia.Pencantuman gambar seram pada kemasan rokok merupakan upaya yang dilakukan pemerintah guna mengurangi jumlah perokok di Indonesia. Sebelum permasalahan rokok beserta visualisasinya ini menjadi prodan kontra, perlu dipahami bahwa ada pergeseran budaya dan pemahaman dasar mengenai sejarah rokok.

Hausten dan David (200o) di dalam bukunya menuturkan sejarah rokok. Rokok sudah ada sejak 10.000 tahun yang lalu, awalnya, rokok hanya digunakan sebagai bagian dari upacara keagamaan yang ada di benua Amerika. Tembakau sebagai bahan dasar membuat rokok dipercaya mampu meningkatkan status manusia dan kemudian dapat membawa manusia pada Tuhan. Kemudian, di dalam perkembangannya, tembakau juga dipercaya dapat menyembuhkan berbagai macam penyakit atau dapat dijadikan sebagai bahan pengobatan.
Bahan dasar rokok, yaitu tembakau tidak hanya dapat ditemukan di Amerika saja tetapi dapat dijumpai di seluruh belahan dunia termasuk Indonesia. Dari sinilah, tembakau dianggap sebagai barang yang mewah. Di sisi lain, beberapa negara melarang penggunaan tembakau seperti Turki, Rusia, Vatikan, dan Jerman. Di Inggris, kemudian tembakau menjadi barang komoditas yang dapat meningkatkan status ekonomi seseorang. Setelah itu, di Spanyol rokok menjadi tanda atau simbol kekuatan kapitalis. Perkembangan ini yang membuat rokok dijumpai dengan berbagai variasi bahan tambahan (Hausten dan David, 200o).

Hausten dan David (2000) juga memberikan penekanan dalam bukunya bahwa Sebelum abad ke-19 peringatan bahaya merokok dengan menggunakan gambar seram sebenarnya sudah digunakan. Memasuki abad ke-19 mulailah rokok diiklankan dengan remaja menjadi sasaran penjualan. Pada era tersebut, mulailah muncul rokok yang ditujukan untuk kaum wanita. Penelitian yang dilakukan pada abad ke20 menyebutkan bahwa rokok yang semula dipercaya dapat menyembuhkan berbagai macam penyakit ternyata menjadi pembunuh nomor satu di dunia.

Sejarah rokok dapat menjelaskan atau menggambarkan bahwa sebenarnya terdapat beberapa fungsi dari rokok sendiri. Terkait dengan fungsi ritual atau keagamaan serta fungsi medis atau pengobatan. Selanjutnya, hal-hal di luar kedua fungsi tersebut ternyata penggunaan gambar seram sebenarnya jauh sudah ada sebelum adanya polemik di berbagai negara terkait dengan gambar seram. Indonesia merupakan salah satu dari negara yang menggunakan gambar seram sebagai bagian dari komunikasi dalam menurunkan jumlah perokok. Merujuk pada fungsi tersebut, dalam perkembangannya rokok menjadi lifestyle atau gaya hidup yang terpola dalam kehidupan sehari-hari.

Sebagai bentuk dari suatu kebiasaan yang dilakukan berulang-ulang, aktivitas merokok merupakan bagian dari tahapan atau proses syang menyebabkan seseorang pada akhirnya menjadi perokok. Leventhal 
\& Clearly (Cahyani, 1995) mengungkapkan bahwa terdapat empat tahapan perilaku dalam merokok hingga menjadi seorang perokok. Pertama, Tahap prepatory merupakan tahapan diamana seseorang mendapatkan gambaran tentang merokok yang menyenangkan dan didasarkan pada yang ditangkap dan dirasakan panca indera. Pada tahap ini seseorang memiliki minat untuk merokok. Kedua, Initiation merupakan tahapan sesorang mulai memikirkan akan melanjutkan merokok atau tidak. Ketiga, ${ }_{2}$ becoming a smoker tahapan dimana seseorang mengkonsumsi rokok empat batang per hari dan berpotensi menjadi perokok. Keempat, maintenance of smoking tahapan seseorang mengatur aktivitas merokok dengan rokok sebagai efek yang menyenangkan. Empat tahapan inilah yang bisa dijadikan pertimbangan bahwa sebenarnya ketika seseorang memutuskan untuk merokok, ada tahapan yang dilalui.

Terdapat beberapa karakteristik perokok yang ada di Indonesia. Data dari infodatin (n.d) menyebutkan bahwa perokok di Indonesia yang berusia di atas 15 tahun pada tahun 2013 didominasi oleh perokok yang berjenis kelamin laki-laki.Tren untuk mulai merokok pada tahun 2013 adalah pada usia antara 15-19 tahun atau termasuk dalam kategori usia remaja. Data tersebut juga menyebutkan bahwa Lampung merupakan wilayah di Indonesia dengan usia remaja perokok terbanyak dibandingkan denga wilayah lain di Indonesia. Data demografis yang diapaparkan oleh infodatin tersebut memperjelas bahwa perokok di Indonesia didominasi oleh perokok yang berusia remaja. Hal tersebut menjadi bagian penting dalam aktivitas kampanye yang ingin disasar adalah mengubah perilaku atau kebiasaan merokok pada usia remaja. Berarti upaya yang dilakukan oleh pemerintah atau aktivis lainnya seharusnya mampu untuk menyasar remaja.

Dalam konteks kehumasan, remaja dan target kampanye ini menjadi bagian dari publik pemerintah. Grunig (Gregory, 2010) menjelaskan bahwa publik adalah siapa saja atau pihak yang diterpa oleh kebijakan dan suatu aktivitas dari organisasi. Berdasarkan konseptualisasi tersebut dapat disimpulkan bahwa pemerintah merupakan organisasi yang dimaksud. Kemudian, para perokok aktif merupakan mereka yang diterpa kebijakan pemerintah terkait dengan adanya gambar seram pada kemasan rokok.

Model SMCR yang diungkapkan Berlo (Mulyana, 2007) apabila diperjelas maka, source (S) didasarkan pada sikapatau perilaku yang diharapkan yang disampaikan oleh pengirim pesan. Message (M) didasarkan pada isi pesan yang divisualisasikan pada kemasan rokok. Channel (C) didasarkan pada indera pengelihatan untuk melihat visualisasi tersebut. Receiver ( $\mathrm{R}$ ) didasarkan pada perubahan sikap atau perilaku yang terjadi pada penerima pesan. Model SMCR ini memperdalam pemahaman terkait dengan komponen dasar pada aspek komunikasi.

Pesan yang disampaikan dalam bentuk pictorical warning pada kemasan rokok merupakan bagian dari kontruksi yang ingin dibangun oleh komunikator atau persuader. Konteks ini mengacu pada pemahaman yang dinyatakan oleh Griffin (2003: 7) pesan dikonstruksikan, diciptakan, direncanakan, dikarang, didapatkan, dipilih, dan diadopsi oleh komunikator. Pictorical warning tersebut juga dipahami sebagai sebuah pilihan yang dilakukan pemerintah dengan mengonstruksi pesan melalui makna dari sebuah gambar. Sebagai bentuk komunikasi, maka "gambar seram" tersebut sudah menjadi bagian dari perencanaan dengan benar agar tujuan yang ingin dicapai dapat terjadi. Akan tetapi, yang menjadi permasalahan adalah seberapa efektif pesan tersebut dapat diterima oleh sebagian besar perokok.

Mengadopsi dari pendapat Perloff (2003) komponen penting persuasi apabila dikaitkan dengan pictorical warning pada kemasan rokok dapat dijabarkan secara lebih rinci. Pertama, Proses simbolik dimaksudkan adalah penggunaan visualisasi "gambar seram" yang tercantum pada kemasan rokok. "Gambar seram" dimaknai sebagai efek jangka panjang maupun jangka pendek yang ditumbulkan dari mengonsumsi rokok secara terus menerus. Penggunaan "gambar seram" pada kemasan rokok diklaim sebagai cara untuk mengendalikan 
konsumsi tembakau. Selain itu, bagi perokok pemula, penggunaan "gambar seram" dapat memberikan secara psikologis (Noorastuti, 2012).

Kedua, persuasi melibatkan bujukan untuk memengaruhi yang dimaksud adalah persuasi yang dilakukan bertujuan untuk merubah sikap atau perilaku tertentu. Konteks dalam kasus ini adalah mengurangi jumlah perokok yang ada di Indonesia. Akan tetapi, proses persuasi berhasil untuk mengubah perilaku perokok. Hal ini tampak pada pernyataan Komnas pengendalian tembakau (Rozak, 2016) yang mengemukakan bahwa penggunaan gambar seram pada kemasan rokok gagal untuk menurunkan jumlah perokok aktif di Indonesia. Komnas pengendalian tembakau juga berpendapat bahwa yang menjadi sasaran dari gambar seram ini tidak tepat. Artinya, akan lebih sesuai apabila ditujukan untuk perokok pasif.

Ketiga, konteks persuader seharusnya menerapkan pesan persuasi pada dirinya sendiri terlebih dahulu kemudian selanjutnya melakukan persuasi kepada orang lain. Konteks kampanye kesehatan ini mengarah pada penyampaian pesan melalui media visualisasi gambar. Sebenarnya, ketika merancang strategi kampanye kesehatan, pemerintah sebagai penyusun kebijakan merefleksikan terlebih dahulu gambaran secara umum berkaitan dengan persuader.

Keempat, proses persuasi melibatkan adanya transmisi pesan. Dikaitkan dengan kasus ini, maka transmisi pesan yang terjadi adalah komunikasi dalam bentuk verbal dan non verbal. Mulyana (2007)menuturkan bahwa bahasa verbal menggunakan kata-kata yang merepresentasi realitas yang ada. Sedangkan, komunikasi verbal menurut Larry dan Porter (dalam Mulyana, 2007) menuturkan bahwa komunikasi non verbal merupakan isyarat dan bukan kata-kata. Berdasarkan kasus yang digunakan, pesan dikomunikasikan melalui gambar dan tulisan. Bentuk pesan yang muncul dari berbagai variasi kemasan rokok yang dijumpai sekarang adalah sebagai berikut:

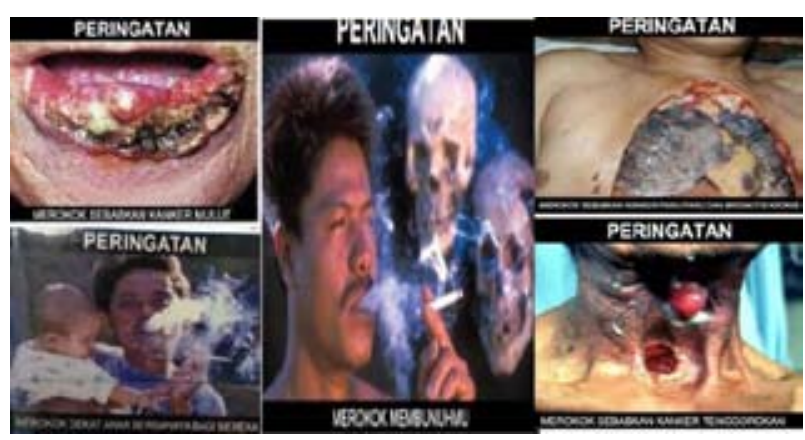

Gambar 1. Variasi "gambar seram" pada kemasan rokok

Sumber: forum.kompas.com

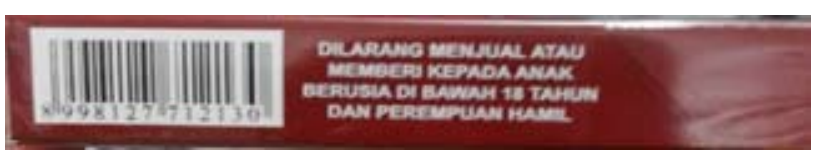

Gambar 2. Peringatan tulisan pada kemasan rokok

Sumber: dokumentasi pribadi peneliti

Kelima, Persuasi membutuhkan pilihan yang dipilih oleh persuade di dalam menentukan perilakunya sendiri. Upaya persuasi yang dilakukan melalui "gambar seram" padakemasan rokok adalah untuk mengurangi jumlah perokok. Penelitian yang pernah dilakukan Negoro (2015) menyebutkan bahwa terdapat penurunan jumlah konsumsi rata-rata batang rokok yang dihisap oleh perokok remaja di Yogyakarta.

Tabel 1 Perbandingan Rata-rata batang rokok sebelum dan sesudah "gambar seram"

\begin{tabular}{|l|l|l|l|l|l|}
\hline \multicolumn{3}{|c|}{$\begin{array}{c}\text { Rata-rata sebelum } \\
\text { "gambar seram" }\end{array}$} & \multicolumn{3}{c|}{$\begin{array}{c}\text { Rata-rata sesudah } \\
\text { "gambar seram" }\end{array}$} \\
\hline$<5$ batang & 37 & $18,5 \%$ & $<5$ batang & 56 & $28 \%$ \\
\hline $6-10$ batang & 88 & $44, \%$ & $6-10$ batang & 82 & $41 \%$ \\
\hline$>10$ batang & 75 & $37,5 \%$ & $>10$ batang & 62 & $31 \%$ \\
\hline
\end{tabular}

Sumber: data sekunder

Berdasarkan data tersebut, dapat dilihat bahwa ada penurunan jumlah konsumsi rokok. Data menunjukkan bahwa adanya distribusi pengurangan rata-rata konsumsi batang rokok dari > 10 batang dan menyebar di 6-10 batang dan $<5$ batang. Mengacu pada poin kelima, bahwa persuade dalam hal ini adalah perokok remaja di Yogyakarta, nampaknya telah menentukan 
perilakunya untuk mengurangi konsumsi rokok yang didasarkan pada penggunaan bahaya merokok dengan visualisasi "gambar seram”. Nampaknya ini merupakan strategi komunikasi yang cukup sesuai dan akhirnya menimbulkan suatu perubahan perilaku walaupun belum semuanya ada pada tataran berhenti merokok.

Kampanye kesehatan dengan menggunakan "gambar seram" pada kemasan rokok yang dilakukan oleh pemerintah dirasa menjadi bagian suatu perencanaan yang sudah dipertimbangkan secara matang. Hal tersebut mengingat upaya pemerintah yang baru direalisasikan pada tahun 2014 padahal kenyataannya, regulasi tentang "gambar seram" sudah ada pada tahun 2012 seperti yang tertuang pada Peraturan Pemerintah Nomor 109 tahun 2012. Dalam kenyataannya, setelah diimplementasikan menimbulkan pro dan kontra mengenai konten gambar tersebut.

Terkait dengan adanya regulasi "gambar seram” pada kemasan rokok, akan menimbulkan suatu perubahan perilaku yang diharapkan dari perokok. Apabila mengacu pada perubahan perilaku setelah ada "gambar seram" pada kemasan rokok dan dikaitkan dengan konsep yang dipaparkan Thomas (2006), maka dapat diuraikan dari masing-masing tahapan. Precontemplation mengacu pada aktivitas perokok yang masih merokok sebagai aktivitas seharihari dengan tidak mempedulikan makna di balik visualisasi yang terpapar pada kemasan rokok. Contemplation merupakan aktivitas dari perokok yang masik merokok akan tetapi di dalam dirinya muncul perasaan bersalah atau ada ketakutan dari aktivitas yang dilakukan. Selanjutnya, decision yang nampak dari perokok yang sudah mulai memutuskan untuk berhenti merokok akan tetapi intensitas merokok belum berkurang. Action dimana perokok mulai mengurangi intensitas merokok sebagai bagian dari usaha untuk berhenti merokok. Terakhir, maintenance adalah bentuk perubahan perilaku perokok itu sendiri untuk tidak merokok lagi.

Perencanaan sebagai usahauntuk meraih tujuan yang ditetapkan yang dilakukan tentunya memiliki alasan yang lebih spesifik mengapa harus diimplementasikan. Apabila dikaitan dengan pemikiran Gregory (2010) pemerintah Indonesia memiliki beberapa alasan tersebut. Penggunaan "gambar seram" pada kemasan rokok menjadi bagian dari usaha pemerintah untuk menekan jumlah perokok di Indonesia mengingat bahaya yang ditimbulkan. Dengan melakukan hal tersebut, dirasa sebagai upaya yang efektif dan efisien. Hal ini dikarenakan kemasan rokok memiliki kedekatan dengan konsumen rokok itu sendiri sehingga mau tidak mau konsumen rokok akan melihat gambar yang terpapar pada kemasan rokok. Akan tetapi, yang menjadi permasalahan bahwa visualisasi gambar pria yang menggendong anak yang terdapat pada kemasan rokok dinilai kurang menunjukkan ukuran "seram" sehingga esensi pesan "gambar seram" yang dibangun tidak dijumpai.

Darisisi kekuasaan, pemerintahmemiliki kekuatan untuk menetapkan regulasi pada semua perusahaan rokok di Indonesia. Dalam artian, mau tidak mau kemasan rokok di semua brand harus mencantumkan "gambar seram" pada kemasan rokoknya dan akan mendapatkan sanksi apabila tidak mencantumkan "gambar seram" tersebut. Sanksi yang diberikan kepada perusahaan rokok apabila tidak mencantumkan "gambar seram" berupa sanksi tertulis dan administrasi (Dewi, 2014). Di sisi yang lain, perusahaan rokok harus menyiapkan strategi yang lain untuk tetap memasarkan produknya. Hal yang substansial bahwa sebenarnya jika dilihat dari strategi pemasaran melalui iklan, justru iklan rokok yang tidak menampilkan wujud fisiknya justru dipandang kreatif dibandingkan dengan iklan lainnya.

Sebagai bagian dari perencanaan itu sendiri, harapan dari adanya kampanye ini adalah mampu meningkatkan efektivitas. Akan tetapi, sebagai penentu kebijakan, pemerintah harus mampu melakukan monitoring dan evaluasi dalam jangka waktu tertentu. Tujuannya adalah melihat tercapai tidaknya suatu indikator atau capaian yang diharapkan. Apabila kegagalan terjadi, maka 
perlu ditinjau kembali faktor-faktor yang menjadi penghambat. Konteks persuasi yang perlu diberi penekanan adalah bahwa persuasi tidak boleh memaksa. Persuasi melibatkan bujukan untuk memengaruhi seseorang (Perloff, 2003). Oleh sebab itu, kampanye kesehatan ini tidak bertujuan untuk memaksa seseorang untuk berubah sesuai dengan perilaku yang diharapkan tetapi memengaruhi seseorang untuk berubah menjadi lebih sehat dari perilaku yang tidak sehat.

Berbekal dari monitoring dan evaluasi yang harus dilakukan, proses kampanye ini menjadi bagian dari suatu proses yang dilakukan secara bertahap. Artinya, ada hal yang diharapkan di setiap tahapan supaya tujuan tersebut dapat dicapai. Perencanaan pada dasarnya juga dibuat dengan perencanaan tambahan atau perencanaan yang lain. Ketika suatu perencanaan pengelolaan "gambar seram" pada kemasan rokok tidak berhasil dilakukan paling tidak masih ada perencanaan yang lain untuk diimplementasikan. Selain itu, sebagai bagian dari suatu manajemen, maka perencanaan diharapkan melihat aspek pembuatan skenario apabila hal buruk terjadi. Kampanye kesehatan melalui "gambar seram" pada kemasan rokok ini diharapkan mampu menjadi jembatan antara perokok pasif yang selama ini juga terkena dampak dari perokok aktif. Akan tetapi, bukan justru akan menimbulkan permasalahan baru karena pada dasarnya program kampanye ini diharapkan mampu untuk mengatasi permasalahan tersebut.

Model EPPM memiliki keterkaitan dengan kampanye kesehatan yang dibuat oleh pemerintah dengan strategi pesan penggunaan "gambar seram" dengan perantara kemasan rokok. Kim Witte (dalam Littlejohn, 2009) mengemukakan bahwa penggunaan visualisasi yang menyeramkan akan menimbulkan efek ketakutan bagi penerima pesan.

Proses efek yang ditimbulkan dimulai dari stimulus eksternal yang diterima oleh perokok. Elemen pesan persuasi pada model EPPM yang melekat pada "gambar seram" di kemasan rokok adalah severity information.
Informasi tentang keseriusan atau besarnya suatu ancaman. Informasi tersebut dapat ditemukan pada kemasan rokok berupa gambar yang menyiratkan bahwa merokok akan meningkatkan resiko kanker mulut, kanker paru-paru, kanker tenggorokan, berbahaya bagi kesehatan anak. Secara lebih spesifik Witte menyebut severity information merupakan bagian dari perceived threat (Popova, 2012), yaitu pengetahuan tentang bahaya yang ada di lingkungan sekitarnya. Pengetahuan mengenai bahaya merokok dari aspek kesehatan yang ditimbulkan dengan adanya perilaku mengonsumsi rokok.

Dari proses tersebut, dapat dilihat bahwa adaduapersoalanefekyang ditimbulkan,yaitu tidak adanya respon dan efek ketakutan yang dialami oleh perokok. Efek ketakutan hanya menimbulkan emosi yang memunculkan motivasi dari dirinya yang kepercayaan itu tidak memberikan respon sehingga pesan menjadi tidak efektif. Secara lebih spesifik yang terjadi adalah penolakan terhadap pesan yang masuk pada diri perokok.

Penggunaan "gambar seram" secara lebih nyata dapat mengganggu dan menimbulkan ketakutan dari perokok remaja. Negoro (2015) dalam penelitiannya menemukan bahwa penggunaan "gambar seram" pada kemasan rokok mengganggu atau menimbulkan perasaan tertentu perokok. Hasil penelitianya dapat ditunjukkan sebagai berikut:

Tabel 2. Perasaan melihat "gambar seram"

\begin{tabular}{|c|c|}
\hline Perasaan & Rerata \\
\hline Perasaan (tidak jijik-jijik) & 5,6 \\
\hline $\begin{array}{c}\text { Perasaan (tidak cemas-cemas) } \\
\text { Perasaan (tidak mengganggu pikiran- } \\
\text { mengganggu pikiran) }\end{array}$ & 4,8 \\
\hline $\begin{array}{c}\text { Perasaan (tidak merasa bersalah-merasa } \\
\text { bersalah) }\end{array}$ & 4,7 \\
\hline Perasaan (tidak marah-marah) & 4,8 \\
\hline
\end{tabular}

Sumber: data sekunder

Hasil rerata diatas menunjukkan bahwa sebenarnya perokok remaja cukup setuju dengan adanya pencantuman "gambar seram" pada kemasan rokok. Akan tetapi, hasil penelitian Negoro (2015) juga mene- 
mukan bahwa sebenarnya perasaan yang muncul ketika melihat gambar seram cenderung negatif. Apabila dikaitkan dengan asumsi model EPPM hasilnya cukup sesuai. Penggunaan gambar seram akan memiliki dampak yang efektif maupun tidak efektif dalam hal penyampaian suatu pesan persuasif (Littlejohn, 2009: 90). Hasil tersebut diperkuat oleh Perloff (2003: 187) yang menyatakan bahwa fear appeal dimaknai sebagai "Komunikasi persuasif yang mencoba untuk menakuti seseorang untuk merubah sikapnya dengan meningkatkan konsekuensi atau dampak negatif yang akan terjadi jika mereka memenuhi rekomendasi suatu pesan".

Perlu dipahami secara lebih lanjut terkait dengan latar belakang atau faktor pendorong yang menyebabkan seseorang memilih aktivitas merokok. Dalam penelitian yang pernah dilakukan oleh Negoro (2016) menyebutkan bahwa aspek lingkungan terutama ajakan teman untuk mencoba rokok merupakan faktor yang dominan yang menyebabkan seseorang merokok. Kemudian, aspek kedua yang menjadi pemicu aktivitas merokok adalah dorongan yang berasal dari dalam diri seseorang atau penasaran atau ingin tahu.

Persoalan kampanye bertema kesehatan ini akan menjadi proses yang cukup panjang. Indonesia boleh saja mengadopsi penggunaan "gambar seram" ini. Bahkan jauh sebelum Indonesia mencoba gagasan "gambar seram" ini pada kemasan rokok, penelitian dari negara lain yang lebih dahulu dilakukan juga tidak begitu saja berhenti dan menjawab permasalahan ini. Bahkan penelitian yang dilakukan Morvan (2011) di Perancis juga menunjukkan bahwa ada pro dan kontra dalam penggunaan visualisasi "gambar seram" pada kemasan rokok. Efektif atau tidaknya suatu pesan persuasif dapat bersumber dari berbagai aspek yang harus terus dieksplor agar pesan yang disampaikan dapat mengubah perilaku tertentu yang memang diharapkan.

\section{SIMPULAN}

Berdasarkan hasil analisis di atas, ditemukan bahwa ada dua hal respon yang ditemukan dari perokok remaja di Yogyakarta. Pertama, bahwa ada dengan adanya penurunan konsumsi rata-rata batang rokok menunjukkan adanya respon dari kalangan perokok remaja. Kedua, respon yang ditunjukkan dari kalangan perokok remaja memiliki kecenderungan negatif. Artinya dampak yang ditimbulkan efektif sebagai bentuk dari pesan persuasif dan sesuai dengan model EPPM oleh Kim Witte.

Pemerintah Indonesia nampaknya harus bekerja keras untuk menyukseskan kampanye kesehatan ini. Program kampanye ini harus dikaji dan dievaluasi secara berkala. Kesuksesan atau kegagalan kampanye bergantung pada pemilihan media yang digunakan dan disesuaikan dengan konteks kebudayaan dan karakteristik dari persuade. Kemudian, aspek terkait dengan proses komunikasi persuasif perlu mempertimbangkan cara yang disesuaikan juga terkait dengan target kampanye. Hal ini dikarenakan karakteristik perokok yang berbeda-beda misalnya, usia, jenis kelamin, sosial ekonomi, dan aspek demografis lainnya.

Sebagai saran, untuk penelitian selanjutnya dapat lebih menggali faktor-faktor penyebab perokok memilih aktivitas rokok. Dapat dikembangkan dalam model penelitian analisis faktor untuk lebih mengeksplor dan dalam melakukan pemetaan sehingga nantinya akan memiliki kekuatan didalam merancang pesan persuasi yang disesuaikan dengan persuade. 


\section{DAFTAR PUSTAKA}

Ardiansyah, Ferry. 2014. 8o Negara adopsi aturan gambar seram di bungkus rokok. Diakses pada 18 Agustus 2016 http://news.okezone.com/ $\mathrm{read} / 2014 / 11 / 24 / 18 / 1069904 / 80$ negara-adopsi-aturan-gambar-seramdi-bungkus-rokok

Blythe, Jim. 2001. Essentials of Marketing Communication. England: Pearson Education Limited.

Cahyani. 1995. Hubungan Antara Persepsi terhadap Merokok dan Kepercayaan Diri dengan Perilaku Merokok pada Siswa STM Muhammadiyah Pakem Sleman. Yogyakarta: Universitas Gadjah Mada Yogyakarta.

Deny, Septian. 2014. YLKI: Gambar seram di bungkus rokok lindungi konsumen. Diakses pada 18 Agustus 2016 http:// bisnis.liputan6.com/read/2069173/ ylki-gambar-seram-di-bungkus-rokoklindungi-konsumen

DeVito, Joseph. 2011. Komunikasi Antarmanusia Edisi Kelima. Jakarta: Karisma Publishing Group.

Dewi, S.N \& Budiawati .A.D. 2014. BPOM Siapkan Sanksi Produsen Rokok Yang TakCantumkan GambarSeram. Diakses pada 5 Desember 2016 http://bisnis. news.viva.co.id/news/read/520013bpom-siapkan-sanksi-produsenrokok-yang-tak-cantumkan-gambarseram

Gelders,D, et al. 2009. The Influence of Warning Message on the Public's Perception of Substance Use: A Theoritical Framework. Government Information Quarterly 26, 349-357.

Gregory, Anne. 2010. Planning and Managing Public Relations Campaigna: A Strategic Approach third edition. United Kingdom: Kogan Page.

Griffin, Em. A first Look at Communication Theory. 2003. Singapore: McGraw Hill Higher Education.
Harrington, N,G,. 2015. Health Communication: Theory, Method, and Application. New York: Routledge.

Hausten, Knut-Olafdan David. 200o. Tobacco or Health $2^{\text {nd }}$ Edition. Germany: Spring.

Heath, R, L., 2005. Encyclopedia of Public Relations. USA: Sage Publciation, Inc.

Ilham. 2015. WHO: Rokok menjadi pembunuh utama. Diakses pada 11 Oktober 2016http://www. republika.co.id/berita/internasional/ global/15/02/o5/nj9ojt-who-rokokmenjadi-pembunuh-utama

Infodatin. (n.d). Perilaku Merokok Masyarakat Indonesia: Berdasarkan Riskedas 2007 dan 2013. Indonesia: Pusat Data dan Informasi Kementerian Kesehatan RI. Diakses pada 1 Desember 2016 http://www.depkes. go.id/resources/download/pusdatin/ infodatin/infodatin-hari-tanpatembakau-sedunia.pdf

Kim, Yungwook. 2003. Conceptualizing Health Campaign Strategies Through the Level of Involvement. Corporate Communication: An International Journal, 8 (4), 255-267.

Littlejohn, S,W, and Foss, K,A,. 2009. Encyclopedia of Communication Theory. USA: Sage Publication.

McCool, J., Webb, L., Cameron, L,D., \& Hoek, J. (2012). Graphic Warning Labels on Plain Cigarette Packs: Will They Make a Difference to Adolescents.Journal of Social Science \& Medicine, 74, 12691273.

Morvan, Gallopel K, et al. 2011 The Use of Visual Warning in Social Marketing: The Case of Tobacco. Journal of Business Research64, 7-11.

Mulyana, Deddy. 2007. Ilmu Komunikasi suatu pengantar. Bandung: Remaja Rosdakarya.

Negoro, Sherly,H. 2015. Pengaruh pengetahuan atas pesan dan persepsi resiko terhadap sikap merokok di kalangan 
perokok remaja Yogyakarta dengan perilaku sebagai variabel intervening. Semarang: Universitas Diponegoro Semarang.

Noorastuti, Pipiet, T,. 2012. Pentingnya gambarseramdibungkusrokok. Diakses pada 26 Oktober 2016 http://life.viva. co.id/news/read/292853-pentingnyagambar-seram-di-bungkus-rokok

Perilaku merokok masyarakat Indonesia berdasarkan Riskesdas 2007 dan 2013. (n.d). Infodatin, h. 1. Diakses pada 1 Agustus $2016 \mathrm{http}: / /$ www.depkes. go.id/download.php?file=download/ pusdatin/infodatin/infodatin-haritanpa-tembakau-sedunia.pdf

Peraturan Pemerintah Nomor 109 Tahun 2012 (n.d). Diakses pada 18 Agustus 2016 http://sipuu.setkab.go.id/ PUUdoc/173643/PP1092012.pdf

Pedoman Pengembangan Kawasan Tanpa Rokok (KTR). 2011. Diakses pada 2 Desember 2016 http://www.depkes. go.id/resources/download/promosikesehatan/pedoman-ktr.pdf

Perloff, Richard, A,. 2003. The Dynamics of Persuasion: communication and attitudes In the 21th century $2^{\text {nd }}$ edition. New Jersey: Lawrence Erlbaum Associates.

Popova, Lucy. 2012. The Extended Parallel Process Model: Illuminating the Gap in Research. Health Education E Behavior 39 (4), 455-473. Diakses pada DOI: 10.1177/1090198111418108 http://heb. sagepub.com.
Puput. 2014. Jumlah perokok meningkat, Indonesia tertinggi kedua di dunia. Diakses pada 18 Agustus 2016 http://lifestyle.bisnis.com/ $\mathrm{read} / 20140601 / 220 / 232021 / \mathrm{jumlah}$ perokok-terus-meningkat-indonesiatertinggi-kedua-di-dunia

Rozak, Abdul. 2016. Gambar seram di bungkus rokok tidak efektif turunkan jumlah perokok. Diakses pada 26 Oktober 2016 http://www.gatra.com/ nusantara/nasional/203019-gambarseram-di-bungkus-rokok-tidak-efektifturunkan-perokok

Schneider, G, and Phau, I,. 2013. Adolsecent and young adult response to fear appeals in anti-smoking messages. Young consumers $14 \quad$ (2), 155166. Diakses pada http://dx.doi. org/10.1108/17473611311325555

Thomas, Richard K. 2006. Health Communication. USA: Springer Science.

Utama, Pradita. 2014. Penguasaha keluhkan gambar 'seram' pada kemasan rokok. Diakses pada 18 Agustus 2016 http://news.metrotvnews.com/ $\mathrm{read} / 2014 / \mathrm{o} 8 / 13 / 276852 /$ pengusahakeluhkan-gambar-seram-padakemasan-rokok 